\section{Original Research}

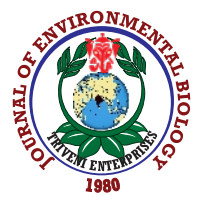

DOI : http://doi.org/10.22438/jeb/41/4/MRN-1270
Journal Home page : www.jeb.co.in ^ E-mail : editor@jeb.co.in Journal of Environmental Biology

p-ISSN: 0254-8704

\title{
Prevalence of mastitis in cow heifers and associated risk factors in Himalayan region, India
}

\section{S. Kour ${ }^{1}$, N. Sharma ${ }^{1 *}$, Z.I. Huma', S. Devi', T. Ahmed', R. Singh ${ }^{1}$ and A. Kumar ${ }^{2}$}

'Division of Veterinary Medicine, Sher-e-Kashmir University of Agricultural Sciences and Technology of Jammu, Jammu-181 102, India ${ }^{2}$ Division of Livestock Product Technology, Sher-e-Kashmir University of Agricultural Sciences and Technology of Jammu, Jammu-181 102, India

*Corresponding Author Email : drneelesh_sharma@yahoo.co.in

\section{Abstract}

Aim: The present study was aimed to understand the prevalence of heifer mastitis and its associated risk factors in Jammu region.

Methodology: A total of 250 pregnant heifers (1000 quarters) were screened, and lacteal secretions were collected from 915 quarters individually, in order to estimate the prevalence of heifers mastitis by culturing. The prevalence was estimated based on the results of microorganism culture.

Results: The overall prevalence of heifer mastitis was $90.80 \%$ by cultural examination whereas only $30 \%$ of the animals produced clinical signs. The prevalence was higher in organized management system and prime risk factors associated with mastitis were season of calving, prepartum intramammary infections, poor udder hygiene, etc., in both organized and unorganized managements.

Interpretation: High prevalence of heifer mastitis (as evidenced by presence of microorganisms) is alarming situation for dairy farming in India. Season of calving, milk leakage at calving, prepartum IMI, poor udder hygiene, sanitation, beddings, floor type, and contact of heifers with older cows could be the important risk factors.

Key Words: Heifer mastitis, Himalayan region, Intramammary infections, Risk factors

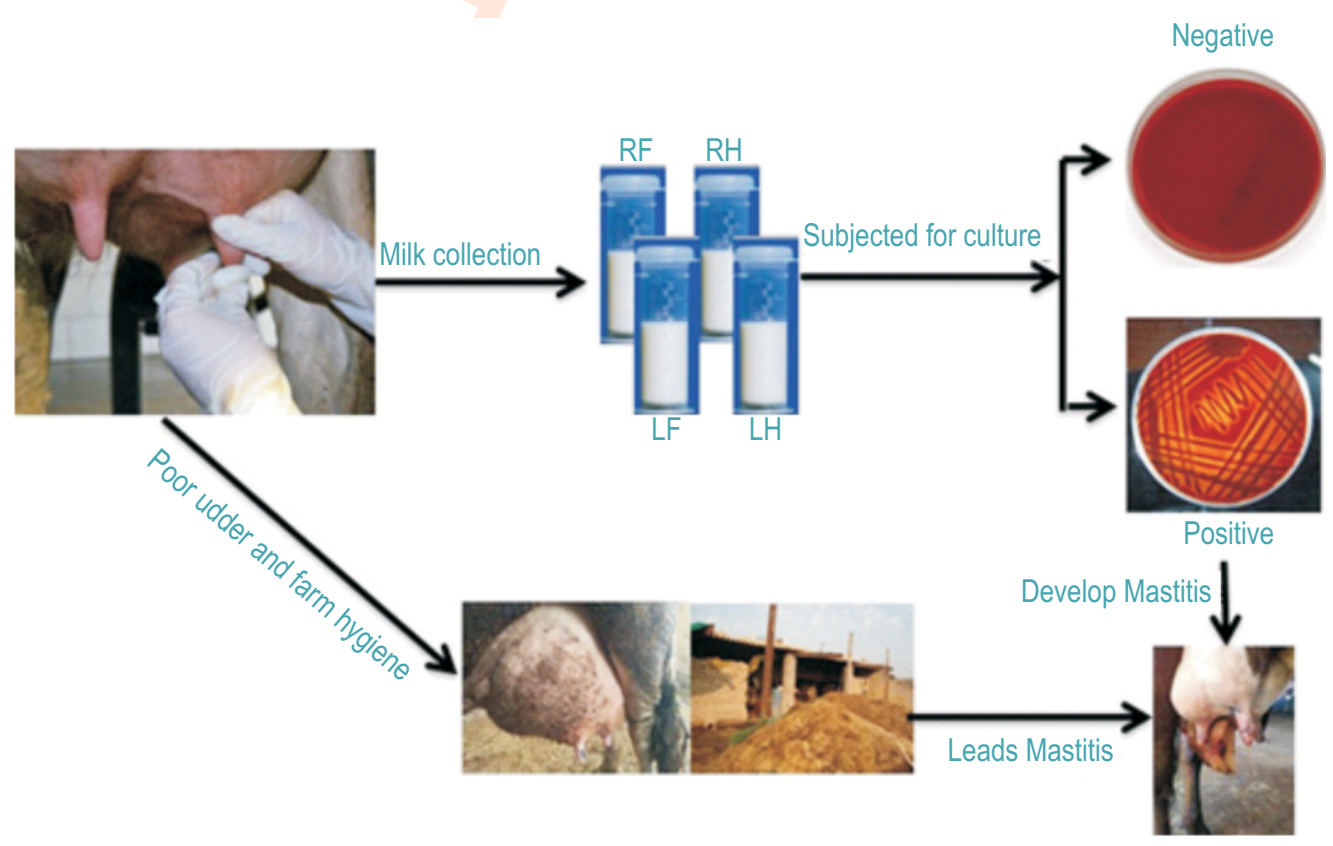

How to cite : Kour, S., N. Sharma, Z.I. Huma, S. Devi, T. Ahmed, R. Singh and A. Kumar: Prevalence of mastitis in cow heifers and associated risk factors in Himalayan region, India. J. Environ. Biol., 41, 796-802 (2020). 


\section{Introduction}

Bovine mastitis, an inflammation of mammary gland, can have infectious or non-infectious etiology (Martins et al., 2015). Heifer mastitis is a disease that potentially threatens production and udder health in the first and subsequent lactation (De Vliegher et al., 2012) leading to economic loss for dairy farms (Piepers etal., 2009).

The massive economic loss to dairy industry is estimated to about Rs. 7165.51 crores/annum (Annual Report, 2008), which has increased about 135 times in last five decades, while in the United States it is estimated to be USD 2 billion/annum (Viguier et al., 2009). In addition to the economic aspects, mastitis adversely affects animal health, milk quality and animal welfare, and there are growing concerns among consumers regarding the development of multi-resistant bacteria resulting from extensive use of antibiotics in farm animals (Holmberg et al., 2012).

Unfortunately, most producers consider young heifers as uninfected, and the presence of mastitis is not observed until calving or first sign of clinical mastitis during early lactation (Vitali et al., 2016). The rate of intramammary infections (IMI) in breeding age and pregnant heifers is much higher. Several potential heifer mastitis risk factors have been identified which include- increased age at first calving, milk leakage (Yang et al., 2015), calving in early summer, increased herd somatic cell count (SCC), presence of organisms on the skin, feeding calves with mastitis milk, contact among calves and with adult cows, absence of antibiotic therapy to heifers, poor milking practices and poor housing conditions (Oliveira et al., 2015). Blood in the milk, udder and teat edema are also considered to be important risk factors (Waage et al., 2001). The presence of IMI before calving increases the risk of infection during lactation (Yang et al., 2015). Transition or periparturient period is a high-risk time for modern dairy cows (Pyorala, 2008). IMl at calving has increased the risk of clinical mastitis within the first week of lactation. Mastitis before parturition and within first week after calving has increased the risk of further cases of mastitis and culling during first 45 days of lactation (Oliveira et al., 2015). Heifer mastitis is mainly caused by Staphylococcus aureus bacteria (Waage et al., 1998). Some studies have reported that Staphylococcus aureus as the most prevalent causative pathogen whereas other studies have reported environmental bacteria to be the more common pathogen (McDougall et al., 2009). Coagulase-negative staphylococci (CNS) are the most common bacteria responsible for the development of heifer mastitis (Breyne et al., 2015) and subclinical mastitis (SCM) in dairy cows (Piccart et al., 2015). Prevalence of subclinical Staphylococcus aureus mastitis and IMI in heifers varies among studies and herds (Owens et al., 2001; Piepers et al., 2010) but is not that prevalent as Coagulase Negative Staphylococci IMI. Environmental pathogens can also cause significant mastitis in prepartum and recently calved heifers (Fox, 2009). Studies on the prevalence and associated risk factors of heifer mastitis in India in general and in Jammu region particular are meager. In view of the above, the present study was conducted to investigate the presence of causative microorganisms for mastitis in heifers and its associated risk factors.

\section{Materials and Methods}

Study area: To understand the occurrence pattern of mastitis, the present study was conducted on various organized and unorganized dairy farms in and around Jammu district. Sampling was done from both government organized farms (poor hygienic practices) and unorganized farms (good hygienic practices).

Prevalence: In total 250 dairy cow heifers were screened. Out of which 217 (795 lacteal secretions) were from organized dairy farms and 33 (120 lacteal secretions) were from unorganized dairy farms. Lacteal secretion samples (915) were taken from the heifers 5 to 10 days before parturition and prevalence of infection was evaluated from the results obtained from microbial culture. The prevalence was expressed in percent.

Collection of lacteal secretions: After proper disinfection of teat surface with $70 \%$ ethyl alcohol, $1-2 \mathrm{ml}$ of lacteal secretion individually from all four quarters, viz. Left Fore (LF), Left Hind (LH), Right Fore (RF) and Right Hind (RH) were collected aseptically after discarding first few streams, in sterile polyethylene screw capped, wide mouth vials from the cow heifers, 5 to 10 days before parturition (Buswell, 1995). The samples were preserved in ice box and carried to the laboratory for further investigation.

Isolation and bacteriological examination: Lacteal samples were subjected to isolation and identification of microorganisms including bacteria and fungi on the basis of morphological, cultural and biochemical characteristics following the method of Buchnan and Gibbons (1984) and according to National Mastitis Council Procedure (2004). In brief, a loopful of each lacteal sample was streaked on blood agar and plates were incubated at $37{ }^{\circ} \mathrm{C}$ for 24 to $36 \mathrm{hr}$ aerobically to record the cultural characteristic of bacterial isolates with respect to size and shape of individual colony and hemolysis ( $\alpha / \beta$ type) on blood agar. Staining of bacterial colonies was done by using Gram's Stain Kit (HiMedia, India; Cat. No. K001) to differentiate Gram-positive and Gram-negative bacteria. These were again confirmed by subjecting to various biochemical tests such as catalase test, oxidase test, coagulase test for Gram-positive organisms and indole production, methyl red test, voges-proskar test, citrate utilization test etc. for Gram-negative bacteria. For further confirmation, isolated micro-organisms were cultured on selective media and confirmed on the basis of their characteristics on their selective media supplied by HiMedia, India. 
Table 1 : Data on various risk factors associated with cow heifers' mastitis

\begin{tabular}{lll}
\hline S.No. & Risk factors & Comparison \\
\hline 1. & Barn size & Adequate/NonAdequate \\
2. & Floor type & Pucca/Kachha \\
3. & Prepartum IMI & Present/Absent \\
4. & Milk leakage at calving & Yes / No \\
5. & Season of calving & Summer/Winter \\
6. & Udder edema & Yes/No \\
7. & Age at calving & Older/young \\
8. & Poor udder hygiene & Yes/No \\
9. & Feeding of waste milk to calves & Yes/No \\
10. & Heifer with old cows & Yes/No \\
11. & Milk quality & Blood in milk/None \\
12. & Plan of nutrition: & Poor/Medium/High \\
13. & Beddings & Yes/No \\
14. & Sanitary practices & Good/Poor \\
\hline
\end{tabular}

Risk factors: Farmers were surveyed to obtain information and epidemiological data. A standard questionnaire was prepared to record all related data to understand the impact of associated risk factors on the occurrence of mastitis in heifer (Table 1).

Statistical analysis : All the data were statistically analyzed by SPSS software (version 16.0 SPSS Inc.) and prevalence values were expressed in per cent. Chi-square test was used for the analysis of risk factors.

\section{Results and Discussion}

During study period, 250 cow heifers were screened in and around Jammu. In total 227 cow heifers were found positive after cultural examination with overall prevalence of $90.80 \%$, and out of them 75 heifers were found to develop clinical signs of mastitis with $30 \%$ prevalence.

Out of 217 cow heifers screened from organized management system, 199 were positive after cultural examination with $91.70 \%$ prevalence whereas in an unorganized farm out of 33 cow heifers screened, 28 were found to be positive after cultural examination with $84.84 \%$ prevalence. Therefore, the prevalence of heifer mastitis by cultural examination was recorded higher in organized management system than the unorganized ones.

In organized management system, out of 217 animals, 66 heifers produced clinical signs with $30.41 \%$ prevalence. The higher prevalence $(22.58 \%)$ of clinical signs was immediate after calving than before calving. In unorganized management system, 9 heifers out of 33 animals screened, produced clinical signs with per cent prevalence of 27.27. However, pattern of occurrence was similar to organized farms with higher prevalence (21.21\%) immediately after calving than before calving.

Out of 1000 quarters screened from the udder of $250 \mathrm{cow}$ heifers, only 915 quarters produced lacteal secretion amongst which 691 quarters were found positive by cultural examination with overall prevalence of $75.51 \%$, and the per cent prevalence of individual quarters (LF, LH, RF, RH) was recorded to be higher in LH followed by RH, LF and RF (Table 2). It was observed that higher number of LH quarters showed clinical signs than others, and on combination basis higher prevalence was observed in hind quarters than fore quarters (Table 2).

The present data on the prevalence of heifer mastitis on animal basis are in confirmation with the reports of Nickerson et al. (1995) and Oliver et al. (1992). However, Pankey et al. (1991) reported $46 \%$ prevalence of heifers' mastitis and $19 \%$ of the quarters were infected during early lactation, while Ospina et al. (2019) reported $64.70 \%$ prevalence of heifers mastitis. Oliver and Sordillo (1988) also reported low (19.70\%) prevalence of heifer mammary glands at calving on the animal basis. Bastan et al. (2015) in Turkish dairy farm reported $37.47 \%$ prevalence of SCM in heifers at the quarter level and mean prevalence of mastitis on farms was calculated as $42.87 \%$ in the study whereas Fox (2009) reported that mammary quarter infection prevalence ranged between 28.90 to $74.60 \%$ prepartum and 12.30 to $45.50 \%$ at parturition. The ability of teat and udder tissues to resist bacterial

Table 2 : Quarter wise prevalence of mastitis in cow heifers by cultural examination and on the basis of clinical signs produced

\begin{tabular}{lllll}
\hline Quarter & $\begin{array}{l}\text { Total no. of } \\
\text { quarters tested }\end{array}$ & $\begin{array}{l}\text { No. of quarters produced } \\
\text { lacteal secretion }\end{array}$ & $\begin{array}{l}\text { No. of quarters positive } \\
\text { after culture }\end{array}$ & $\begin{array}{l}\text { No. of quarters produced } \\
\text { clinical signs }\end{array}$ \\
\hline LF & 250 & 209 & $154(73.68 \%)$ & $54(25.83 \%)$ \\
LH & 250 & 236 & $193(81.77 \%)$ & $69(29.23 \%)$ \\
RF & 250 & 240 & $161(67.08 \%)$ & $57(23.75 \%)$ \\
RH & 250 & 230 & $183(79.56 \%)$ & $65(28.26 \%)$ \\
On combination basis & & & \\
Fore quarter & 500 & 449 & $315(70.15 \%)$ & $119(26.50 \%)$ \\
Hind quarter & 500 & 466 & $376(80.68 \%)$ & $126(27.03 \%)$ \\
Total & 1000 & 915 & $691(75.51 \%)$ & $245(26.77 \%)$ \\
\hline
\end{tabular}


challenge during calving period is diminished and susceptibility to infection is increased (Slettbakk et al., 1995). The immune system of dairy cows is suppressed during periparturient period (Payorala, 2008) due to about five folds increase in the blood cortisol concentration and $17 \beta$-oestradiol levels occur at the day of parturition (Lamote et al., 2004). There is paucity of literature with reference to heifer mastitis in India in general and in Jammu and Kashmir region in particular.
In the present study, higher prevalence of SCM both on individual and quarter basis might be attributed to poor managemental practices in dairy farm, various environmental factors and lack of awareness of dairyman towards early diagnostic tests and timely treatment of mastitis affected cows. In the present study, infection rate was higher in the hind quarters, which is well documented that hind quarters are always at higher risk to come in the direct contact of animal urine and uterine

Table 3 : Descriptive and bivariate $\mathrm{x}^{2}$ analysis of responses to questions related to the epidemiology and risk factors associated with mastitis in and around Jammu

\begin{tabular}{|c|c|c|c|c|c|c|c|c|c|c|}
\hline \multirow[t]{2}{*}{ Variable } & \multicolumn{2}{|c|}{ Mastitis (Organized) } & \multirow[t]{2}{*}{$x^{2}$} & \multirow[t]{2}{*}{ O.R } & \multirow[t]{2}{*}{$\mathrm{p}$-value } & \multicolumn{2}{|c|}{ Mastitis(Unorganized) } & \multirow[t]{2}{*}{$x^{2}$} & \multirow[t]{2}{*}{ O.R } & \multirow[t]{2}{*}{$\mathrm{p}$-value } \\
\hline & Yes & No & & & & Yes & No & & & \\
\hline \multicolumn{11}{|c|}{ Season of calving } \\
\hline Summer & 55 & 39 & \multirow[t]{2}{*}{61.854} & \multirow[t]{2}{*}{14.35} & \multirow[t]{2}{*}{$0.000^{*}$} & 8 & 6 & \multirow[t]{3}{*}{10.938} & \multirow[t]{3}{*}{24} & \multirow[t]{2}{*}{$0.001^{*}$} \\
\hline Winter & 11 & 112 & & & & 1 & 18 & & & \\
\hline \multicolumn{9}{|c|}{ Milk leakage at calving } & & \\
\hline Yes & 57 & 61 & \multirow[t]{2}{*}{39.115} & \multirow[t]{2}{*}{9.34} & \multirow[t]{2}{*}{$0.000^{*}$} & 8 & 9 & \multirow[t]{2}{*}{6.920} & \multirow[t]{2}{*}{13.2} & $0.009^{*}$ \\
\hline No & 9 & 90 & & & & 1 & 15 & & & \\
\hline Prepartum IMI & & & & & & & & & & \\
\hline Yes & 39 & 43 & 18.309 & 3.624 & $0.000^{*}$ & 8 & 4 & 14.754 & 40 & $0.000^{*}$ \\
\hline No & 27 & 108 & & & & 1 & 20 & & & \\
\hline Milk Quality at & & & & & & & & & & \\
\hline Blood/Pus & 60 & 6 & 47.502 & 14.745 & $0.000^{*}$ & 1 & 22 & 20.111 & 0.0112 & $0.000^{*}$ \\
\hline Normal & 6 & 90 & & & & 8 & 2 & & & \\
\hline Udder Edema & & & & & & & & & & \\
\hline Yes & 3 & 16 & 2.105 & 0.401 & 0.147 & 8 & 18 & 0.755 & 2.64 & 0.385 \\
\hline No & 63 & 135 & & & & 1 & 6 & & & \\
\hline Udder Hygien & & & & & & & & & & \\
\hline Poor & 63 & 106 & 17.005 & 8.91 & $0.000^{*}$ & 8 & 12 & 4.146 & 8 & $0.042^{*}$ \\
\hline Good & 3 & 45 & & & & 1 & 12 & & & \\
\hline Age at calving & & & & & & & & & & \\
\hline Older & 54 & 114 & 1.050 & 1.458 & 0.306 & 7 & 18 & 0.028 & 1.167 & 0.868 \\
\hline Younger & 12 & 37 & & & & 2 & 6 & & & \\
\hline Feeding of Wa & Ailk to & & & & & & & & & \\
\hline Yes & 66 & 151 & - & - & - & 8 & 6 & 10.938 & 24 & $0.001^{*}$ \\
\hline No & - & - & & & & 1 & 18 & & & \\
\hline Barn size & & & & & & & & & & \\
\hline Adequate & 66 & 151 & - & - & - & 7 & 22 & 1.185 & 0.318 & 0.276 \\
\hline Non adequate & - & - & & & & 2 & 2 & & & \\
\hline Floor type & & & & & & & & & & \\
\hline Pucca & 66 & 151 & - & - & - & 8 & 9 & 6.920 & 13.2 & $0.009^{*}$ \\
\hline Kaccha & - & - & & & & 1 & 15 & & & \\
\hline Beddings & & & & & & & & & & \\
\hline Present & - & - & - & - & - & 8 & 9 & 6.920 & 13.2 & $0.009^{*}$ \\
\hline Absent & 66 & 151 & & & & 1 & 15 & & & \\
\hline Plan of Nutriti & & & & & & & & & & \\
\hline Good & 66 & 151 & - & - & - & 8 & 12 & 4.146 & 8 & $0.042^{*}$ \\
\hline Poor & - & - & & & & 1 & 12 & & & \\
\hline Contact of hei & rcows & & & & & & & & & \\
\hline Yes & 57 & 61 & 39.115 & 9.34 & $0.000^{*}$ & 8 & 9 & 6.920 & 13.2 & $0.009^{*}$ \\
\hline No & 9 & 90 & & & & 1 & 15 & & & \\
\hline Sanitation & & & & & & & & & & \\
\hline Good & - & - & - & - & - & 5 & 22 & 5.738 & 13.2 & $0.017^{*}$ \\
\hline Poor & 66 & 151 & & & & 4 & 2 & & & \\
\hline
\end{tabular}


discharge, which is a rich source of infection. During present study, it was also observed that farmers were not aware about the possibilities of mastitis in heifers. Most importantly, it is believed that mastitis occurs only in lactating animals. Variation in the prevalence of SCM in heifers may be attributed to the selection of animals, season, breed and other managemental factors. A possible explanation for this finding could be that most farmers in the study area do not practice proper farming management and screening for mastitis at earlier stage.

Risk factors : The study was conducted in farms, and the farmers were surveyed for collecting information and the epidemiological data to identify the risk factors associated with cow heifer mastitis. A standard questionnaire was prepared to record all the related data and to understand the impact of associated risk factors on the occurrence of mastitis in cow heifers. After completion of survey, the results were analyzed by descriptive and bivariate $\chi^{2}$ analysis to evaluate the association of risk factors with the occurrence of mastitis. In organized management system, risk factors such as season of calving, milk leakage at calving, prepartum IMI, milk quality at calving, udder hygiene, contact of heifers with adult cows showed significant relation with respect to the development of mastitis, while factors such as feeding of mastitic milk to calves, barn size, floor type, beddings, plan of nutrition could not be analyzed statistically due to lack of counter values based on which these factors were to be analyzed (Table 3, Fig. 1).

In unorganized management system, in addition to the above factors feeding of mastitic milk to calves, floor type, beddings, plan of nutrition and sanitation also showed significant results with respect to development of mastitis. Udder edema and age at calving both factors showed non-significant relation with the development of mastitis in organized as well as unorganized management system while barn size also contributed to nonsignificant results in case of unorganized farms (Table 3). The present data on the risk factors of heifer mastitis on animal basis are in confirmation with the reports of Waage et al. (2001) and Bastan et al. (2015). Waage et al. (2001) reported that herd size, composition of diet, an increase in age at first calving etc. are associated with increased risk of mastitis. Bastan et al. (2015) found that the number of animals in the herd, composition of diet, mixing of cows, and the status of contact of heifers with older cows significantly increase the risk for mastitis. Ruegg (2011) indicated that feeding well-balanced ration was among the risk factors for subclinical heifer mastitis and is fundamental for optimal immunity and the ability of animals to resist disease. Recently, Etifu and Tilahun (2019) also reported that milk yield, hygiene score, feet problems and udder conformation have significant $(P<0.05)$ association with the development of mastitis. In this study, feeding a well-balanced ration was an important risk factor as it reduced the incidence of mastitis in heifers. This can be explained by the fact that the rate of udder oedema is low and udder immune system is strong in herds fed with well-balanced rations.

McDougall et al. (2009) reported that udder oedema is a well-recognized risk factor for mastitis in heifers and a combination of genetics and ration contributes to the development of udder oedema in heifers. On the contrary, udder oedema is not a responsible risk factor for the development of mastitis in this study. The reason for this outcome can be related to feeding of well balanced ration and animals with good udder immune system. Although, milk leakage at calving was a potential risk factor in this study. Streptococcus agalactiae was one of the most prevalent bacteria responsible for SCM in heifers and contact of heifers with older cows increased the rate of SCM. Furthermore, contact with mastitic cows can increase the transmission of bacteria to pregnant heifers. Barkema et al. (1999) and Ruegg (2011) indicated that contact of heifers with older cows before calving increase the risk of clinical mastitis after calving. Therefore, separation of heifers from older cows has been recommended.

Bedding type, which has low humidity and lower amount of nutrients available to bacteria and is also made of inorganic material, is ideal for dairy cows. Inorganic bedding material houses fewer coliform bacteria compared to organic material. In the present study, we determined that bedding material did not affect the incidence of sub-clinical heifer mastitis in organized farms, but significantly affected the animals in unorganized farms. OldeRiekerink et al. (2007) reported that risk of mastitis varies with season and climate. A seasonal effect has been related to an elevated SCC in heifers postpartum. It was found that SCC spikes were most frequent in heifers during summers. Whist et al. (2007) also indicated that SCC was highest in summer. These results are in accordance with the results of this study.

High prevalence of heifer mastitis is alarming situation for dairy farming in India and this study enhances the interest of researchers and veterinary clinicians to emphasize on the control of mastitis at the heifers stage itself. The results of possible risk factors from the present study may be targeted for controlling mastitis in heifers.

\section{Acknowledgment}

The authors thankfully acknowledge the financial support received from the ICAR-Extramural Project from Animal Science Division, Indian Council of Agricultural Research, New Delhi, India.

\section{References}

Annual Report. GADVASU, Ludhiana, India (2008).

Barkema, H.W., Y.H. Schukken, T.J. Lam, M.L. Beiboer, G. Benedictus and $A$. Brand: Management practices associated with the incidence rate of clinical mastitis. J. Dairy Sci., 82, 1643-1654 (1999). 
Bastan, A., S. Salar, M. Cengiz, I. Darbaz, M.A. Demirel and D. Ozen: The prediction of the prevalence and risk factors for sub clinical heifer mastitis in Turkish dairy farms. Turk. J. Vet. Anim. Sci., 39, 682-687 (2015).

Breyne, K., S. De Vliegher, A. De Visscher, S. Piepers and E. Meyer: Technical note: A pilot study using a mouse mastitis model to study differences between bovine associated coagulase-negative staphylococci. J. Dairy Sci., 98, 1090-1100 (2015).

Buchnan, R.E. and N.E. Gibbon: Bergeys Manual of Determinative Bacteriology. $8^{\text {th } E d n ., ~ T h e ~ W i l l i a m s ~ a n d ~ W i l k i n s ~ C o m p a n y ~}$ Baltimore, U.S.A(1984).

Buswell, J.: Simple mastitis bacteriology for the practice. In Practice, 17, 426-432 (1995).

Compton, C.W.R., C. Heurer, K. Parker and S. McDougall: Risk factors for peripartum mastitis in pasture-grazed heifers. J. Dairy Sci., 90, 4171-4180 (2007).

De Vliegher, S., L.K. Fox, S. Piepers, S. McDougall and H.W. Barkema: Invited review: Mastitis in dairy heifers: Nature of the disease, potential impact, prevention, and control. J. Dairy Sci., 95, 10251040 (2012).

Erb, H.N., R.D. Smith, P.A. Oltenacu, C.L. Guard, R.B. Hillman, P.A. Powers, M.C. Smith and M.E. White: Path model of reproductive disorders and performance, milk fever, mastitis, milk yield and culling in Holstein cows.J. Dairy Sci., 68, 3337-3349 (1985).

Etifu, M. and M. Tilahun.: Prevalence of bovine mastitis, risk factors, isolation and anti-bio gram of major pathogens in Mid Rift Valley, Ethiopia. Int. J. Livest. Prod., 10, 14-23 (2019).

Fox, L.K.: Prevalence, incidence and risk factors of heifer mastitis. Vet. Microbiol., 134, 82-88 (2009).

Holmberg, M., W.F. Fikse, L. Andersson-Eklund, K. Artursson and A. Lunden: Genetic analyses of pathogen-specific mastitis. J. Anim. Breeding Genet., 129, 129-137. (2012).

Pyorala, S.: Mastitis in post-partum dairy cows. Reprod. Domest. Anim., 43, 252-259 (2008).

Kalmus, P., A. Viltrop, B. Aasmae and K. Kask: Occurance of clinical mastitis in primiparous Estonian dairy cows in different housing conditions. Acta Vet. Scand., 48, 21-29 (2006).

Lamote, I., E. Meyer, L. Duchateau and C. Burvenich: Influence of $17 \beta$ estradiol, progesterone, and dexamethasone ondiapedesis and viability of bovine blood polymorpho-nuclear leukocytes. J. Dairy Sci., 87, 3340-3349 (2004).

Martin-Richard, M.: Prevalence of mastitis in heifers and associated risk factors. In: Proceedings of $3^{\text {rd }}$ Symposium de Calidad de Leche $y$ Seguridad Alimentaria. Leon, Spain, pp. 59-61 (2001).

Martins, K.B., P.Y. Faccioli-Martins, D.F.M. Riboli, V.C. Pereira, S. Fernandes, A.A. Oliveira, A. L.F.D. Zafalon and da M.L.R.S. Cunha: Clonal profile, virulence and resistance of Staphylococcus aureus isolated from sheep milk. Braz. J. Microbiol., 46, 535-543 (2015).

McDougall, S., K.I. Parker, C. Heuer and C.W.R. Compton: A review of prevention and control of heifer mastitis via non-antibiotic strategies. Vet. Microbiol., 134, 177-185 (2009).

National Mastitis Council: Microbiological Procedures for the Diagnosis of Bovine Udder Infection and Determination of Milk Quality. NMC publication, (2004). https://trove.nla.gov.au/version/44357531

Nickerson, S.C., W.E. Owen and R.L. Boddie: Mastitis in dairy heifers: Initial studies on prevalence and control. J. Dairy Sci., 78, 16071618 (1995).
OldeRiekerink, R.G.M., H.W. Barkema and H. Stryhhn: The effect of season on somatic cell count and the incidence of clinical mastitis. J. Dairy Sci., 90, 1704-1715 (2007).

Oliveira, C.S.F., H. Hogeveen, A.M. Botelho, P.V. Maia, S.G. Coelho and J.P.A. Haddad: Cow-specific risk factors for clinical mastitis in Brazilian dairy cattle. Prev. Vet. Med., 121, 297-305 (2015).

Oliver, S.P. and L.M. Sordillo: Udder health in periparturient period. J. Dairy Sci., 71, 2584-2606 (1988).

Oliver, S.P., M.J. Lewis, B.E. Gillespie and H.H. Dowlen: Influence of prepartum antibiotic therapy on intramammary infections in primigravid heifers during early lactation. J. Dairy Sci., 75, 406-414 (1992).

Oltenacu, P.A. and I. Ekesbo: Epidemiologic-study of clinical mastitis in dairy-cattle. Vet. Res., 25, 208-212 (1994).

Ospina, P.A. V. Alanis, A.K. Vasquez, F. Welcome, T. Tomazi, R. Watters, K. Marel and D.V. Nydam: Heifer Mastitis - What About it? In: 58th Annual Meeting of the National Mastitis Council, pp. 27-53 (2019).

Owens, W.E., S.C. Nickerson, R.L. Boddie, G.M. Tomita and C.H. Ray: Prevalence of mastitis in dairy heifers and effectiveness of antibiotic therapy. J. Dairy Sci., 84, 814-817 (2001).

Pankey, J.W., P.A. Drechsler and E.E. Wildman: Mastitis prevalence in primigravid heifers at parturition. J. Dairy Sci., 74, 1550-1552 (1991).

Piccart, K., S. Piepers, J. Verbeke, N.M. De Sousa, J.F. Beckers and S. De Vliegher: Milk prolactin response and quarter milk yield after experimental infection with coagulase-negative staphylococci in dairy heifers. J. Dairy Sci., 98, 4593-4600 (2015).

Piepers, S., S. De Vliegher, A. De Kruif, G. Opsomer and H.W. Barkema: Impact of intramammary infections in dairy heifers on future udder health, milk production, and culling. Vet. Microbiol., 134, 113-120. (2009).

Piepers, S., G. Opsomer, H.W. Barkema, A. de Kruif and S. De Vliegher: Heifers infected with coagulase-negative staphylococci in early lactation have fewer cases of clinical mastitis and higher milk production in their first lactation than noninfected heifers. J. Dairy Sci., 93, 2014-2024 (2010).

Pyorala, S.: Mastitis in post-partum dairy cows. Reprod. Domest. Anim., 43, 252-259 (2008).

Ruegg, P.: Heifer mastitis: How to help heifers calve clean. In: Proceedings of Dairy Calf and Heifer Conference. Geneva, Switzerland: Dairy Calf and Heifer Association, 5-6 (2011). https://en.engormix.com/dairy-cattle/articles/heifer-mastitis-howhelp-t35706.htm

Schreiner, D.A. and P.L. Ruegg: Relationship between udder and leg hygiene scores and subclinical mastitis. J. Dairy Sci., 86, 34603465 (2003).

Slettbakk, T., A. Jorstad, T.B. Farver and J.C. Holms: Impact of milking characteristics and morphology of udder and teats on clinical mastitis in first-and second-lactation Norwegian cattle. Prev. Vet. Med., 24, 235-244 (1995).

Trinidad, P., S.C. Nickerson and T.K. Alley: Prevalence of intramammary infection and teat canal colonization in unbred and primigravid dairy heifers. J. Dairy Sci., 70, 107-114 (1990).

Viguier, C., S. Arora, N. Gilmartin, K. Welbeck and R. O'Kennedy: Mastitis detection: Current trends and future perspectives. Trends Biotechnol., 27, 486-493 (2009). 
Vitali, A., U. Bernabucci, A. Nardone and N. Lacetera: Effect of season, month and temperature humidity index on the occurrence of clinical mastitis in dairy heifers. Adv. Anim. Biosci., 7, 250-252 (2016).

Waage, S., S.A. Odegaard, A. Lund, S. Brattegierd and T. Rothe: Casecontrol study of risk factors for clinical mastitis in postpartum dairy heifers. J. Dairy Sci., 84, 392-399 (2001).
Waage, S., S. Sviland and S.A. Odegaard: Identification of risk factors for clinical mastitis in dairy heifers. J. Dairy Sci., 81, 1275-1284 (1998).

Whist, A.C., O. Osteras and L. SØlverØd: Streptococcus dysgalactiae isolates at calving and lactation performance within the same lactation. J. Dairy Sci., 90, 766-778 (2007).

Yang, F.L., C. Shen, B.X. He, Y.Y. Yang and X.S. Li: The prevalence of heifer mastitis and its associated risk factors in Huanggang, Central China. Trop. Anim. Hlth. Prod., 47, 87-92 (2015). 